U.S.D.A. Forest Service Research Paper INT - 54

1968

\title{
FLAMMABILITY OF HERBICIDE-TREATED GUAVA FOLIAGE
}

C. W. Philpot and R. W. Mutch

This research was partially supported by the

Advanced Research Projects Agency

Department of Defense

ARPA Order 818

This document has been cleared for open publication

INTERMOUNTAIN FOREST AND RANGE EXPERIMENT STATION

Forest Service

U.S. Department of Agriculture

Ogden, Utah 84401

Joseph F. Pechanec, Director 